\title{
Application of a tangent curve mathematical model for analysis of the mechanical behaviour of sunflower bulk seeds
}

\author{
Riswanti Sigalingging1,2*, David Herák², Abraham Kabutey², Oldřich Dajbych², Petr Hrabě̉, \\ and Čestmír Mizera ${ }^{2}$ \\ ${ }^{1}$ Department of Agricultural Engineering, University of Sumatera Utara, \\ Prof. A. Sofyan No. 3 Kampus USU, Medan, Indonesia Republic \\ ${ }^{2}$ Department of Mechanical Engineering, ${ }^{3}$ Department of Material Science and Manufacturing Technology, \\ Czech University of Life Sciences Prague, Kamycka 129, Praha 6, Czech Republic
}

Received February 5, 2015; accepted October 20, 2015

\begin{abstract}
A b s t r a c t. This paper evaluate the use of a tangent curve mathematical model for representation of the mechanical behaviour of sunflower bulk seeds. Compression machine (Tempos Model 50, Czech Republic) and pressing vessel diameter $60 \mathrm{~mm}$ were used for the loading experiment. Varying forces between 50 and $130 \mathrm{kN}$ and speeds ranging from 10, 50, and $100 \mathrm{~mm}$ $\mathrm{min}^{-1}$ were applied respectively on the bulk seeds with moisture content $12.37 \pm 0.38 \%$ w.b. The relationship between force and deformation curves of bulk seeds of pressing height $80 \mathrm{~mm}$ was described. The oil point strain was also determined from the different deformation values namely $30,35,40$, and $45 \mathrm{~mm}$ at speed $10 \mathrm{~mm} \mathrm{~min}^{-1}$. Based on the results obtained, model coefficients were determined for fitting the experimental load and deformation curves. The validity of these coefficients were dependent on the bulk seeds of pressing height, vessel diameter, maximum force $110 \mathrm{kN}$, and speed $10 \mathrm{~mm} \mathrm{~min}^{-1}$, where optimal oil yield was observed. The oil point was detected at $45 \mathrm{~mm}$ deformation giving the strain value of 0.56 with the corresponding force $16.65 \pm 3.51 \mathrm{kN}$ and energy $1.06 \pm 0.18 \mathrm{MJ} \mathrm{m}^{-3}$. At the force of $130 \mathrm{kN}$, a serration effect on the curves was indicated; hence, the compression process was ceased.
\end{abstract}

K e y w o r d s: oil bearing crop, linear compression, energy requirement, oil point, Mathcad 14 software

\section{INTRODUCTION}

Sunflower (Helianthus annuus L.) is an annual plant belonging to the family (Asteraceae) growing up to a height of $4.6 \mathrm{~m}$. The plant has large, rough, and hairy leaves and flower heads grow between 20 and $30 \mathrm{~cm}$ in diameter. The

*Corresponding author e-mail: riswanti@usu.ac.id seeds, which are oval in shape, contain very nutritious oil composition including vitamins (B-1, B-5, B-6), tannins, inulin, levulin, magnesium, selenium, phosphorus, tryptophan, copper, magnesium, folate, fiber, iron, zinc, amino acids, and Omega-3 fatty acid (Arsah and Amjad, 2012; Madhavi et al., 2010). Sunflower oil is also suitable for non-food purposes such as biodiesel or vegetable-oil based fuel for many vehicles (Pereyra-Irujo et al., 2009).

For medicinal use, sunflower seeds possess antioxidant, anti-inflammatory, diuretic, and expectorant properties. These include the reduction of asthma symptoms, osteoarthritis, and rheumatoid arthritis as well as bronchial, pulmonary, and laryngeal problems. They can also be applied as an addition to therapy of colon cancer, high blood pressure, and migraine headaches. As a result of its magnesium content, the seeds can be used against heart attacks and strokes. Sunflower leaves can also be used as an infusion to treat high fevers, lung problems, and diarrhea, and the roots against snake and spider bites (Arsah and Amjad, 2012; Madhavi et al., 2010).

For extraction of oil from bulk seeds, mechanical pressing has been the most common technique especially in the rural areas of developing countries. Other methods such as solvent, enzyme assisted, and supercritical fluid extractions have been feasible for oil extraction from sunflower seeds and other oilseeds. The combination of mechanical pressing and solvent extraction processes gives better

(C) 2015 Institute of Agrophysics, Polish Academy of Sciences 
results than either method applied individually. In spite of all these available methods, factors such as pressure, temperature, pressing time, and moisture content greatly affect oil yield during extraction processes of oilseeds (Evon et al., 2014; Khan and Hanna 1983; Willems et al., 2008). To improve the oil extraction and energy utilization efficiency using mechanical methods such as screw presses or expellers, modification in press design and optimization of process parameters have been considered (Toscano and Pedretti, 2007). Mathematical models based on Darcy law and simulation programmes including a linear programme for optimization and a discrete element method (Mrema and McNulty, 1985; Owolarafe et al., 2008; Raji and Favier 2004) have also been employed in modelling and optimization of oil recovery efficiency. These processes revealed that pressure is the most vital variable for consideration, since higher pressure increases oil percentage although it could generate higher temperature, which subsequently affects the quality of the oil either for food or biofuel production (Omobuwajo et al., 1998; Venter et al., 2007; Willems et al., 2008).

In monitoring and setting the required pressure for pressing the oil from oilseeds, it is necessary to understand the mechanical behaviour of bulk oilseeds and their mathematical description under compression loading (Gupta and Das, 1997). In the literature, such studies have been described in detail on jatropha bulk oilseeds compared to other oilseed crops such as rape, soybean, safflower, sunflower etc., where most studies have been focused on moisture-dependent physical and engineering properties (Bhise et al., 2013; de Figueiredo et al., 2011; Mirzabe et al., 2012; Moya et al., 2013; Tarighi et al., 2011). In compression loading, the bulk oilseed is measured into a pressing vessel or chamber with holes beneath, which allows leakage of the oil while the solid part or the seed cake remains in the pressing vessel. The oil yield in this case is usually determined as the ratio of the mass of oil (the difference between initial mass of bulk seeds and mass of press cake) to that of the initial mass of bulk seeds. For example, the oil yield of jatropha bulk seeds has been found to range between $0.88 \pm 0.05$ and $27.45 \pm 0.13 \mathrm{~g}$, depending on the bulk seeds moisture content, pressing height, vessel diameter, amount of force, and speed (Kabutey et al., 2015).

Based on the compression test, a mathematical model applying the tangent curve function has been developed for describing the mechanical behaviour and the deformation characteristic curve of different bulk oilseeds. The tangent curve function (Herák et al., 2011) is described as follows:

$$
F(x)=A[\tan (B x)]^{n},
$$

where: $A$ is the force coefficient of the mechanical behaviour $(\mathrm{N}), B$ is the deformation coefficient of the mechanical behaviour $\left(\mathrm{mm}^{-1}\right)$, and $n$ is the exponent of the fitted curve function. The Mathcad 14 software with the Levenberg-Marquardt algorithm for data fitting optimal for tangent curve approximation provides a very simple mathematical algorithm for the tangent curve mathematical model development. The application of the software does not require advanced computer memory for data processing unlike simulation programmes such as the finite element method (Petrů et al., 2012). From the point of experimental and mathematical knowledge, the development of the tangent curve mathematical model takes into account the compression loading boundary conditions. These boundary conditions are as follows: when the force is increasing to infinity, the deformation reaches the maximum limit, zero compressive force means zero deformation, and the integral of the tangent curve function is the energy.

Identification of the oil point of bulk oilseeds is also relevant to the dynamics of the mechanical behaviour, which is influenced by such factors as porosity, contact pressure, gradients of pressure, and compressibility (Faborode and Favier, 1996; Herák et al., 2013; Omobuwajo et al., 1998; Rusinek et al., 2012). In-depth information of oil point detection of sunflower bulk seeds in compression loading is required to develop suitable mathematical models for the description of the compression process by maximizing oil yield efficiency with minimum energy utilization.

The aim of the study was to describe the load-deformation characteristics of sunflower bulk seeds based on the tangent curve mathematical model. Parameters such as deformation, energy, oil yield, oil point strain, oil point force, and oil point energy were evaluated.

\section{MATERIALS AND METHODS}

Sunflower bulk seeds purchased from Ceska Skalice, Czech Republic, were subjected to a mechanical compression test using a compression machine (Tempos Model 50, Czech Republic). A pressing vessel diameter $60 \mathrm{~mm}$ with a plunger was used. Various compressive forces from 50 , $70,90,110$, and $130 \mathrm{kN}$ and speed 10,50 , and $100 \mathrm{~mm} \mathrm{~min}^{-1}$ were applied on the bulk seeds of pressing height $80 \mathrm{~mm}$.

The initial moisture content of the bulk seeds was determined using the standard hot air oven method with a temperature setting of $105^{\circ} \mathrm{C}$ and a drying time of $17 \mathrm{~h}$ (ISI, 1966). The electronic balance (Kern 440-35, Kern \& Sohn GmbH, Balingen, Germany) with an accuracy of $0.001 \mathrm{~g}$ was used for weighing the samples before and after oven drying. The mean moisture content of sunflower bulk seeds $12.37 \pm 0.38 \%$ w.b. was calculated using the equation given by (Blahovec, 2008). The data obtained was a repetition of three experiments which was analyzed by ANOVA using STATISTICA software (Statsoft, 2010) and Mathcad software 14 (MathCAD 14, PTC Software, Needham MA, USA), (Pritchard, 1988), which uses the LevenbergMarquardt algorithm for data fitting (Marquardt, 1963). 


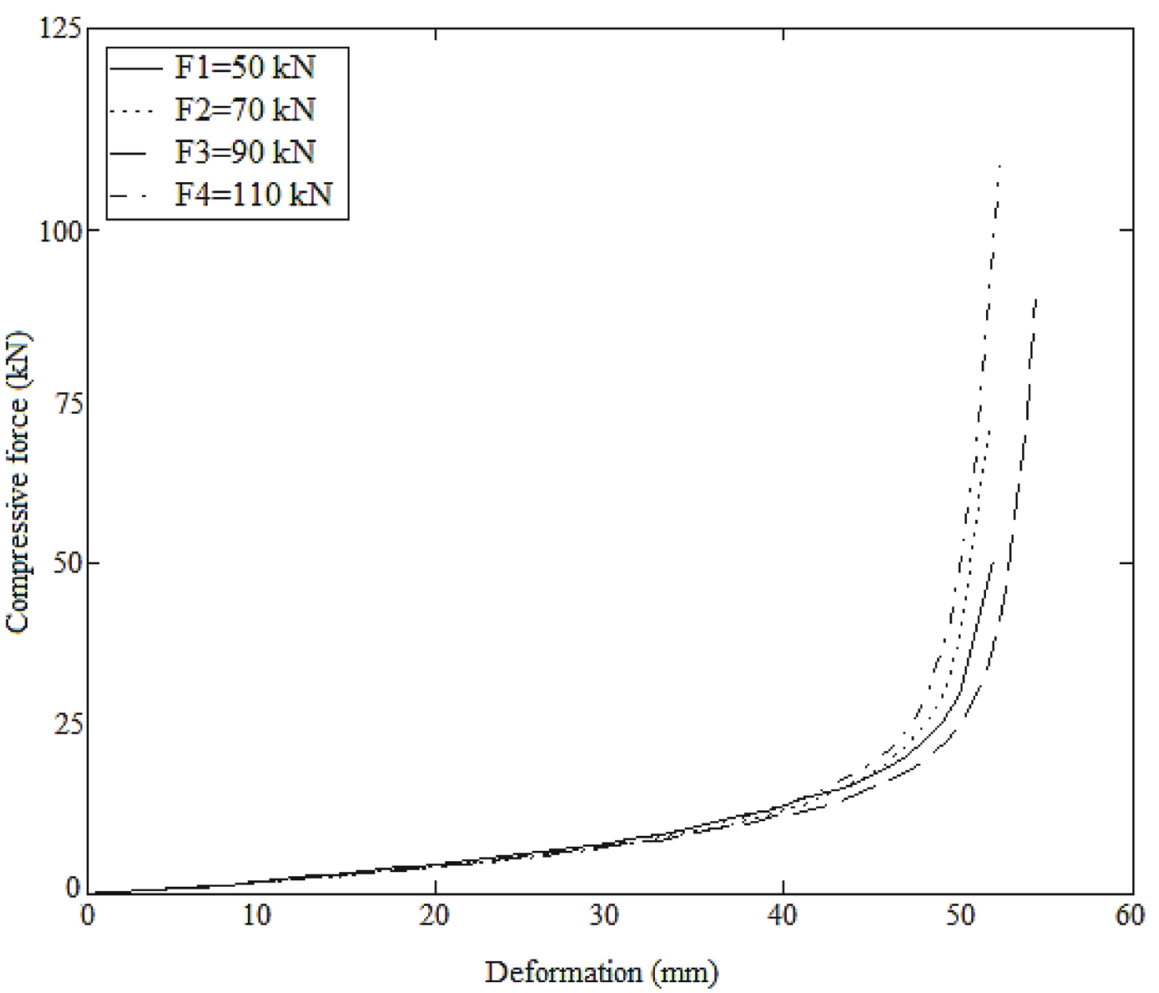

Fig. 1. Compressive force and deformation characteristic curves of sunflower bulk seeds at speed $10 \mathrm{~mm} \mathrm{~min}^{-1}$.

The Mathcad algorithm makes use of function derivations to search coefficients for fitting the experimental data. The oil yield was determined using the equation reported by Kabutey et al. (2015).

The deformation energy which represents the area under the force-deformation curve was calculated applying the equation given by (Sigalingging et al., 2014). The oil point or the first leakage of the oil was visually observed from the positions of the $0.2 \mathrm{~mm}$ holes of the vessel diameter for each deformation value of $30,35,40$, and $45 \mathrm{~mm}$ applied on the bulk sunflower seeds (Herák et al., 2013).

\section{RESULTS AND DISCUSSION}

The dependence between the force and deformation curves of sunflower bulk seeds in relation to the varying forces at a constant speed $10 \mathrm{~mm} \mathrm{~min}{ }^{-1}$ is illustrated in (Fig. 1). Similar results were observed at constant speeds 50 and $100 \mathrm{~mm} \mathrm{~min}^{-1}$. Higher force of $130 \mathrm{kN}$ demonstrated a serration effect on the deformation curves. This behaviour contributed to ejection of crushed sunflower seeds through the positions of the $0.2 \mathrm{~mm}$ holes beneath the pressing vessel. As a result, the compression test was set at maximum force of $110 \mathrm{kN}$. The serration effect has been also reported among the bulk seeds of jatropha, rape, and sunflower at constant force of $100 \mathrm{kN}$ and speed $60 \mathrm{~mm} \mathrm{~min}{ }^{-1}$ (Divišová et al., 2014). The experimental relationship between the force and deformation characteristic curve of sunflower bulk seeds was theoretically fitted by the tangent curve model (Sigalingging et al., 2014).
Figure 2 shows the experimental data fitted by the tangent curve model at speed $10 \mathrm{~mm} \mathrm{~min}{ }^{-1}$ and maximum force $110 \mathrm{kN}$, for which the highest oil yield of the sunflower bulk seeds was obtained. Statistical analysis of the tangent model coefficients determined for fitting the experimental data are presented in Table 1. The results were statistically significant based on the evaluation that the critical values $\left(\mathrm{F}_{\text {crit }}\right)$ were higher than the value of F-tests $\left(\mathrm{F}_{\text {ratio }}\right)$ as well as p-values being greater than the significant value of 0.05 . The coefficients of determination $\left(\mathrm{R}^{2}\right)$ values of the determined model coefficients also explain the suitability of the tangent curve mathematical model for representation of deformation curve characteristics of sunflower bulk seeds under compression loading. The validity of these coefficients is limited from zero deformation to maximum deformation of the bulk seeds. It also depends on the bulk seeds pressing height, vessel diameter, maximum force and speed.

Tables 2 and 3 present the experimental and statistical results of the measured parameters of sunflower bulk seeds. For deformation, the different forces at constant speeds 10 and $50 \mathrm{~mm} \mathrm{~min}^{-1}$ were not statistically significant $(\mathrm{p}>0.05)$ compared to speed $100 \mathrm{~mm} \mathrm{~min}^{-1}$, which was significant $(\mathrm{p}<0.05)$.

On the other hand, oil yield and energy were statistically significant $(\mathrm{p}<0.05)$. Obviously, higher speed reduces the residence time of the oil to discharge from the bulk oilseeds (Kabutey et al., 2015). 


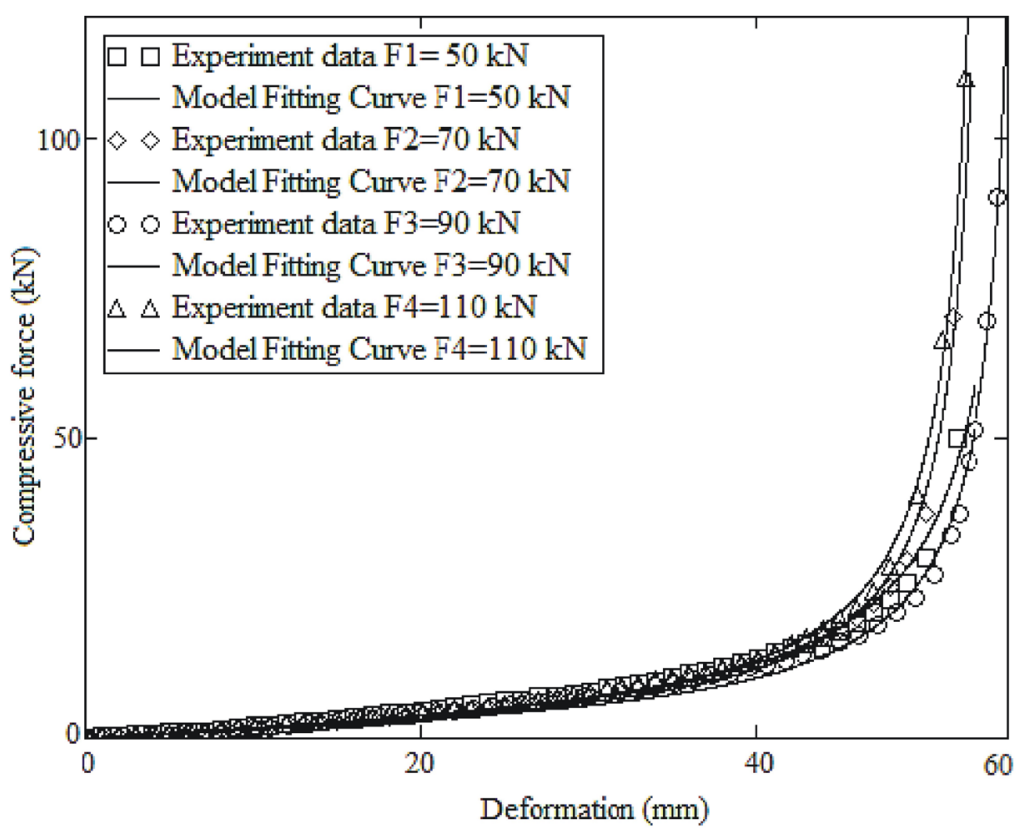

Fig. 2. Mechanical behaviour of sunflower bulk seeds at speed $10 \mathrm{~mm} \mathrm{~min}^{-1}$ fitted by the tangent curve model.

T a b l e 1. Determined coefficients of the tangent curve model and statistical analysis of sunflower bulk seeds (exponent of the deformation curve $\mathrm{n}=1$ )

\begin{tabular}{cccccccc}
\hline $\begin{array}{c}\text { Force } \\
(\mathrm{kN})\end{array}$ & $\begin{array}{c}\text { Speed } \\
\left(\mathrm{mm} \mathrm{min}^{-1}\right)\end{array}$ & $\begin{array}{c}A \\
(\mathrm{kN})\end{array}$ & $\begin{array}{c}B \\
\left(\mathrm{~mm}^{-1}\right)\end{array}$ & $\mathrm{F}_{\text {ratio }}$ & $\mathrm{F}_{\text {crit }}$ & $\mathrm{p}$-value & $\mathrm{R}^{2}$ \\
\hline 50 & & 6.283 & 0.028 & 0.030 & 3.934 & 0.862 & 0.988 \\
70 & & 5.083 & 0.029 & 0.031 & 3.934 & 0.861 & 0.994 \\
90 & 10 & 5.044 & 0.028 & 0.035 & 3.934 & 0.852 & 0.996 \\
110 & & 5.662 & 0.029 & 0.005 & 3.934 & 0.945 & 0.997 \\
50 & & 5.271 & 0.029 & 0.008 & 3.934 & 0.927 & 0.998 \\
70 & & 4.942 & 0.029 & 0.014 & 3.934 & 0.907 & 0.998 \\
90 & 50 & 5.500 & 0.031 & 0.003 & 3.934 & 0.957 & 0.996 \\
110 & & 5.860 & 0.030 & 0.001 & 3.934 & 0.997 & 0.995 \\
50 & & 5.159 & 0.031 & 0.002 & 3.934 & 0.961 & 0.999 \\
70 & & 5.070 & 0.031 & 0.006 & 3.934 & 0.937 & 0.999 \\
90 & 100 & 5.681 & 0.310 & 0.005 & 3.934 & 0.998 & 0.998 \\
110 & & 6.692 & 0.030 & 0.011 & 3.934 & 0.917 & 0.987 \\
\hline
\end{tabular}

$A$ - force coefficient of the mechanical behaviour, $B$-deformation coefficient of the mechanical behaviour, $\mathrm{F}_{\text {crit }}$ is the critical value that compares a pair of models, $\mathrm{F}_{\text {ratio }}$ is the value of the $\mathrm{F}$ test, $\mathrm{p}$-value is the significance level at which the hypothesis of equality of models can be rejected, $\mathrm{R}^{2}$ is the measure of goodness of fit of the relationship between variables.

In this study, the optimal speed for higher oil recovery efficiency from sunflower bulk seeds using vessel diameter $60 \mathrm{~mm}$ and measured bulk seed height $80 \mathrm{~mm}$ was observed at the speed $10 \mathrm{~mm} \mathrm{~min}^{-1}$, suggesting that maximum oil yield could be obtained at the lower speed. This hypothetical lower speed requires further verification in industrial technology involving mechanical screw presses to determine the efficient and economical speed for higher percentage oil from sunflower bulk seeds.

In compression loading, the vessel diameter and amount of compressive force also have an influence on oil yield (Divišová et al., 2014). Therefore, in future research, there 
T a b l e 2. Evaluation of force and speed on deformation, energy, and oil yield of sunflower bulk seeds (mean \pm standard deviation)

\begin{tabular}{|c|c|c|c|c|}
\hline Compressive force $(\mathrm{kN})$ & Speed $\left.(\mathrm{mm} \mathrm{min})^{-1}\right)$ & Deformation $(\mathrm{mm})$ & Energy $\left(\mathrm{MJ} \mathrm{m}^{-3}\right)$ & Oil yield $(\mathrm{g})$ \\
\hline 50 & \multirow{4}{*}{10} & $51.57 \pm 0.41$ & $1.97 \pm 0.10$ & $17.99 \pm 1.01$ \\
\hline 70 & & $52.59 \pm 0.80$ & $2.17 \pm 0.08$ & $18.87 \pm 0.54$ \\
\hline 90 & & $53.04 \pm 1.23$ & $2.42 \pm 0.04$ & $20.09 \pm 1.30$ \\
\hline 110 & & $52.71 \pm 1.43$ & $2.60 \pm 0.13$ & $21.71 \pm 0.94$ \\
\hline 50 & \multirow{4}{*}{50} & $49.99 \pm 0.37$ & $1.85 \pm 0.03$ & $11.43 \pm 1.11$ \\
\hline 70 & & $50.32 \pm 0.98$ & $2.04 \pm 0.04$ & $12.25 \pm 0.57$ \\
\hline 90 & & $49.16 \pm 0.37$ & $2.24 \pm 0.09$ & $13.34 \pm 0.88$ \\
\hline 110 & & $51.14 \pm 1.04$ & $2.62 \pm 0.06$ & $15.07 \pm 0.34$ \\
\hline 50 & \multirow{4}{*}{100} & $47.60 \pm 0.35$ & $1.79 \pm 0.03$ & $9.13 \pm 0.51$ \\
\hline 70 & & $48.28 \pm 0.62$ & $2.07 \pm 0.02$ & $10.57 \pm 0.54$ \\
\hline 90 & & $49.15 \pm 0.31$ & $2.39 \pm 0.10$ & $13.26 \pm 1.22$ \\
\hline 110 & & $50.66 \pm 0.32$ & $3.52 \pm 0.44$ & $17.84 \pm 2.39$ \\
\hline
\end{tabular}

T a b l e 3. ANOVA Analysis of the varying effect of force on the measured data of sunflower bulk seeds at different speed

\begin{tabular}{|c|c|c|c|c|}
\hline Measured data & Speed $\left(\mathrm{mm} \mathrm{min}{ }^{-1}\right)$ & $\mathrm{R}^{2}$ & F-value & $\mathrm{p}$-value \\
\hline Deformation (mm) & & 0.29 & 1 & $>0.05$ \\
\hline Energy $\left(\mathrm{MJ} \mathrm{m}^{-3}\right)$ & 10 & 0.91 & 26 & $<0.05$ \\
\hline Oil yield (g) & & 0.75 & 8 & $<0.05$ \\
\hline Deformation (mm) & & 0.56 & 3 & $>0.05$ \\
\hline Energy $\left(\mathrm{MJ} \mathrm{m}^{-3}\right)$ & 50 & 0.97 & 83 & $<0.05$ \\
\hline Oil yield (g) & & 0.82 & 12 & $<0.05$ \\
\hline Deformation (mm) & & 0.91 & 30 & $<0.05$ \\
\hline Energy $\left(\mathrm{MJ} \mathrm{m}^{-3}\right)$ & 100 & 0.93 & 33 & $<0.05$ \\
\hline Oil yield (g) & & 0.89 & 23 & $<0.05$ \\
\hline
\end{tabular}

Significant $(\mathrm{p}<0.05)$, not significant $(\mathrm{p}>0.05)$.

is a need to analyze the relationships between oil recovery efficiency, compressive force, and vessel diameter. Such factors as moisture content, bulk seed maturity, and genotype should be studied to fully understand the mechanical behaviour of bulk sunflower seeds.

The deformation value of $45 \mathrm{~mm}$ was denoted as the oil point as presented in (Fig. 3). The oil point value defines the minimum force required to cause oil flow from the bulk seeds. Compressive force and energy corresponding to the oil point strain of 0.56 were found to be approximately $16.65 \pm 3.51 \mathrm{kN}$ and $1.06 \pm 0.18 \mathrm{MJ} \mathrm{m}^{-3}$, respectively (Table 4).
The energy value was observed to be higher than the literature value of $3.69 \pm 0.90 \mathrm{~J}$ (Rusinek et al., 2012) and this difference could be due to the varying factors including bulk seed moisture content, volume of bulk seeds, force, speed, and vessel diameter.

Finally, the relationship between oil yield and oil point strain of sunflower bulk seeds was fitted by a linear trend as shown in (Fig. 4). However, the validity of this fitted function is limited only at the region of deformation characteristic curve with oil flow. Since only three points were obtained, the validity of the function is highly compromised. 
T a b l e 4. Oil point detection of sunflower bulk seeds at speed $10 \mathrm{~mm} \mathrm{~min}^{-1}$ (mean \pm standard deviation)

\begin{tabular}{ccccc}
\hline Deformation $(\mathrm{mm})$ & Strain & Oil yield $(\mathrm{g})$ & Force $(\mathrm{kN})$ & ${\text { Energy }\left(\mathrm{MJ} \mathrm{m}^{-3}\right)}^{-3}$ \\
\hline 30 & $0.38 \pm 0.00$ & $0.00 \pm 0.00$ & $6.25 \pm 0.66$ & $0.36 \pm 0.06$ \\
35 & $0.44 \pm 0.00$ & $0.00 \pm 0.00$ & $7.89 \pm 0.85$ & $0.50 \pm 0.06$ \\
40 & $0.50 \pm 0.00$ & $0.06 \pm 1.07$ & $9.79 \pm 1.01$ & $0.65 \pm 0.07$ \\
45 & $0.56 \pm 0.00^{*}$ & $8.02 \pm 3.85$ & $16.65 \pm 3.51$ & $1.06 \pm 0.18$ \\
\hline
\end{tabular}

*Oil point strain of sunflower bulk seeds at pressing height $80 \mathrm{~mm}$ and vessel diameter $60 \mathrm{~mm}$.

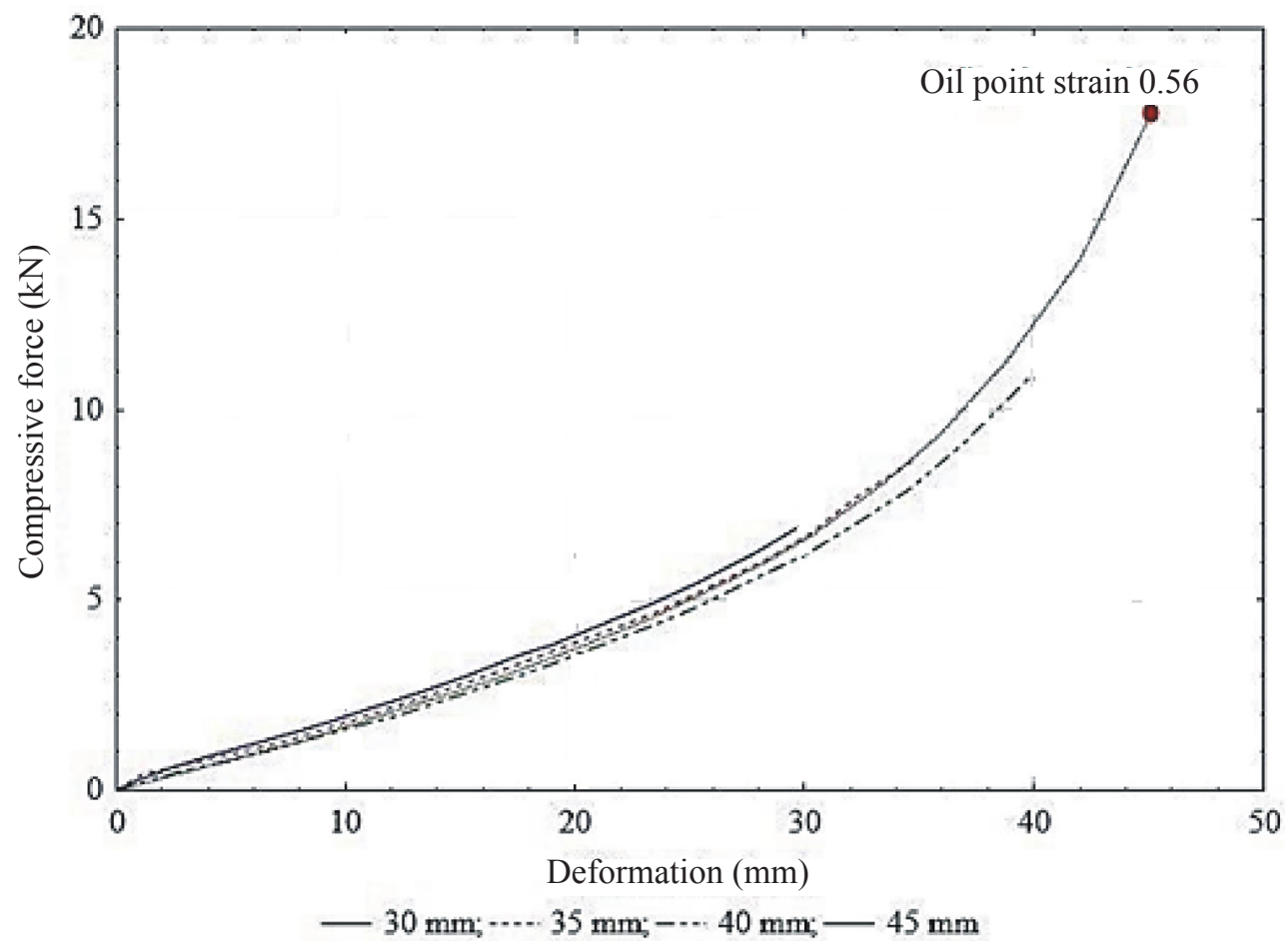

Fig. 3. Compressive force and deformation values for detection of oil point strain of sunflower bulk seeds at speed $10 \mathrm{~mm} \mathrm{~min}^{-1}$.

\section{CONCLUSIONS}

1. Tangent curve model coefficients were determined for fitting the experimental dependence between compressive force and deformation curves of bulk sunflower seeds. The coefficients are valid for sunflower bulk seeds at pressing height $80 \mathrm{~mm}$, vessel diameter $60 \mathrm{~mm}$, forces between 50 and $110 \mathrm{kN}$, and speeds 10,50 , and $100 \mathrm{~mm} \mathrm{~min}^{-1}$.

2. Energy and oil yield amounts were significant $(\mathrm{p}<0.05)$ at varying forces between 50 and $110 \mathrm{kN}$ at constant speeds 10,50 , and $100 \mathrm{~mm} \mathrm{~min}^{-1}$, respectively.

3. Deformation values were only significant $(\mathrm{p}<0.05)$ at speed $100 \mathrm{~mm} \mathrm{~min}^{-1}$.

4. Optimal oil yield was observed at speed $10 \mathrm{~mm} \mathrm{~min}^{-1}$ and force $110 \mathrm{kN}$.
5. The oil point was noticed at deformation of $45 \mathrm{~mm}$ with a strain value of 0.56 . The corresponding amounts of force and energy were $16.65 \pm 3.51 \mathrm{kN}$ and $1.06 \pm 0.18 \mathrm{MJ} \mathrm{m}^{-3}$, respectively.

6. Maximum force of $130 \mathrm{kN}$ showed a serration effect on the force-deformation curves.

\section{REFERENCES}

Arsah M., and Amjad M., 2012. Medicinal use of sunflower oil and present status of sunflower in pakistan: A Review Study. Sci. Tech. Dev., 31, 99-106.

Blahovec J., 2008. Agromaterials-Study Guide-Czech University of Life Sciences Prague, 7-8. 


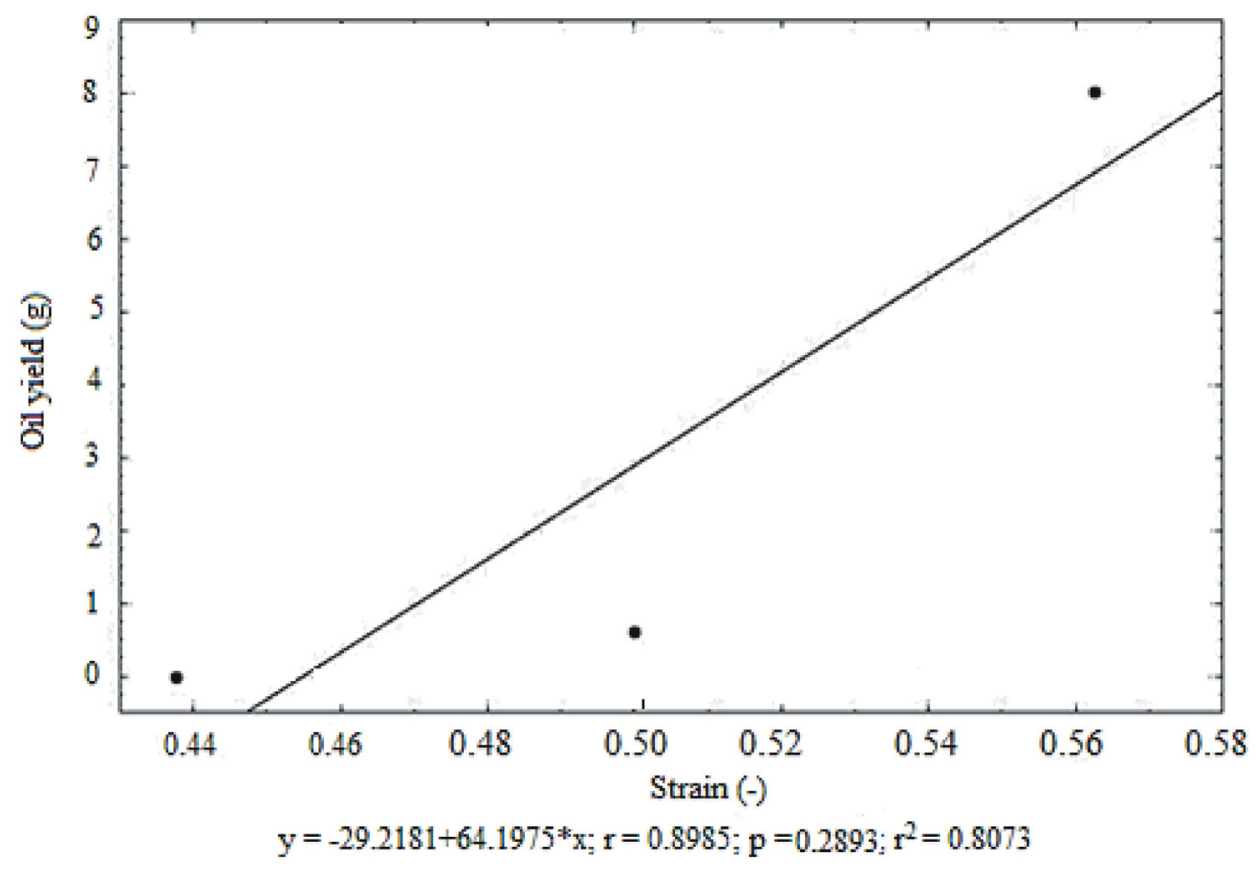

Fig. 4. Linear relationship between oil yield and strain of sunflower bulk seeds at speed $10 \mathrm{~mm} \mathrm{~min}^{-1}$.

Bhise S., Kaur A., and Manikantan M.R., 2013. Moisture dependant physical properties of sunflower seed (Psh 569). Int. J. Eng. Sci., 2, 23-27.

de Figueiredo A.K., Baümler E., Riccobene I.C., and Nolasco S.M., 2011. Moisture-dependent engineering properties of sunflower seeds with different structural characteristics. J. Food Eng., 102, 58-65.

Divišová M., Herák D., Kabutey A., Šleger V., Sigalingging R., and Svatoňová T., 2014. Deformation curve characteristics of rape seeds and sunflower seeds in compression loading. Scientia Agriculturae Bohemica, 45, 180-186.

Evon P., Vinet J., Labonne L., and Rigal L., 2015. Influence of thermo-pressing conditions on the mechanical properties of biodegradable fiberboards made from a deoiled sunflower cake. Industrial Crops Products, 65, 117-126.

Faborode M.O. and Favier J.F., 1996. Identification and significance of the oil-point in seed-oil expression. J. Agric. Eng. Res., 65, 335-345.

Gupta R. K. and Das S. K., 1997. Physical properties of sunflower seeds. J. Food Eng., 66, 1-8.

Herák D., Kabutey A., Sedlacek A., and Gurdil G., 2011. Tangent curve utilization for description for mechanical behavior of pressed mixture. Res. Agric. Eng., 57, 13-18.

Herák D., Kabutey A., and Hrabe P., 2013. Oil point determination of Jatropha curcas L. bulk seeds under compression loading. Biosystems Eng., 116, 470-477.

ISI, 1966. Indian standard methods for analysis of oilseeds. IS: 3579. Indian Standard Institute, New Delhi, India.

Kabutey A., Herák D., Chotěborský R., Sigalingging R., and Mizera C., 2015. Effect of compression speed on energy requirement and oil yield of Jatropha curcas L. bulk seeds under linear compression. Biosystems Eng., 136, 8-13.

Khan L.M., and Hanna M.A., 1983. Expression of oil from oilseeds - a review. J. Agric. Eng. Res., 28, 495-503.
Madhavi B., Devi N.K.D., Mrudula B.S., and Babu R.N., 2010. The importance of biodegradable bio-oil-sunflower. Int. J. Pham. Tech. Res., 2, 1913-1915.

Marquardt D.W., 1963. An algorithm for the least-squares estimation of nonlinear parameters. SIAM J. Applied Mathematics, 11, 431-441.

Mirzabe A. H., Khazaei J., and Chegini G. R., 2012. Physical properties and modeling for sunflower seeds. Agric. Eng. Institute, CIGR J., 14, 190-202.

Moya M., Aguado P.J., and Ayuga F., 2013. Mechanical properties of some granular agricultural materials used in silo design. Int. Agrophys., 27, 181-193.

Mrema G.C. and McNulty P.B., 1985. Mathematical model mechanical oil expression from oilseeds. J. Agric. Eng. Res., 31, 361-370.

Omobuwajo T.O., Ige M.T., and Ajayi A.O., 1998. Theoretical prediction of extrusion pressure and oil flow rate during screw expeller processing of palm kernel seeds. J. Food Eng., 38, 469-485.

Owolarafe O.K., Osunleke A.S., Odejobi O.A., and Faborode M.O., 2008. Mathematical modeling and simulation of the hydraulic expression of oil Palm fruit. Biosystems Eng., 101, 331-340.

Pereyra-Irujo G.A., Izquierdo N.G., Covi M., Nolasco S.M., Quiroz F., and Aguirrezábal L.A.N., 2009. Variability in sunflower oil quality for biodiesel production: A simulation study. Biomass Bioenergy, 33, 459- 468.

Petrů M., Novák O., Herák D., and Simanjuntak S., 2012. Finite element method model of the mechanical behaviour of Jatropha curcas L. seed under compression loading. Biosystems Eng., 111, 412-421.

Pritchard P.J., 1998. Mathcad: A tool for engineering problem solving. McGraw-Hill Science Engineering, New York, USA. 
Raji A.O. and Favier J.V., 2004. Model for the deformation in agricultural and food particulate materials under bulk compressive loading using discrete element method II: Compression of oil seeds. J. Food Eng., 64, 373-380.

Rusinek R., Rybczyński R., Tys J., Gawrysiak-Witulska M., Nogala-Kałucka M., and Siger A., 2012. The process parameters for non-typical seeds during simulated cold deep oil expression. Czech J. Food Sci., 30, 126-134.

Sigalingging R., Herák D., Kabutey A., Čestmír M., and Divišová M., 2014. Tangent curve function description of mechanical behavior of bulk oilseeds: a review. Scientia Agriculturae Bohemica, 45, 259-264.

Statsoft, 2010. Inc. Tulsa, OK74104, USA.
Tarighi J., Mahmoudi A., and Rad M.K., 2011. Moisturedependet engineering properties of sunflower (var. Armaviriski). Australian J. Agric. Eng., 2, 40-44.

Toscano G. and Pedretti E.F., 2007. Evaluation of a mathematical model for oil extraction from Oleaginous seeds. J. Ag. Eng. - Riv. di Ing. Agr., 2, 11-20.

Venter M.J., Kuipers N.J.M., and De Haan A.B., 2007. Modelling and experimental evaluation of high-pressure expression of cocoa nibs. J. Food Eng., 80, 1157-1170.

Willems P., Kuipers N.J.M., and De Haan A.B., 2008. Hydraulic pressing of oilseeds: experimental determination and modeling of yield and pressing rates. J. Food Eng., 89, 8-16. 